\title{
FOLIAGE PRESERVATIVES FOR VASE LIFE EXTENSION OF TWO DIEFFENBACHIA SPECIES
}

\author{
Senuri Thambugala ${ }^{1}$, Krishanthi Abeywickrama ${ }^{1}$ and Sisira Karunarathna ${ }^{2}$ \\ ${ }^{1}$ Department of Botany, Faculty of Science, University of Kelaniya,Sri Lanka. \\ ${ }^{2}$ Green Farms Pvt. Ltd., Marawila, Sri Lanka \\ Accepted 23 December 2010
}

\begin{abstract}
Cut foliage of Dieffenbachia maculata and Dieffenbachia amoena were subjected to continuous treatment with several foliage preservatives and export simulation. The preservatives used were $1.75 \%$ of sodium hypochlorite, 5\% vinegar and $\mathrm{Vim}^{\mathrm{TM}}$ dish washing detergent. Tap water without any added chemicals was used as the control. The highest vase life of 45.1 days was observed in D. maculata cut foliage when subjected to continuous treatment with tap water. Cut foliage of $D$. maculata subjected to continuous treatment with $0.016 \%(\mathrm{v} / \mathrm{v})$ dish washing detergent $\left(\mathrm{Vim}^{\mathrm{TM}}\right)$ solution and $0.016 \%(\mathrm{v} / \mathrm{v})$ sodium hypochlorite $(\mathrm{NaOCl})$ and subjected to export simulation for two days at $12-14^{0} \mathrm{C}$ and $85-90 \%$ relative humidity $(\mathrm{RH})$, had relatively longer vase life of 38.9 days and 37 days respectively. Cut foliage of D. amoena had the longest vase life of 21 days when subjected to $0.016 \% \mathrm{NaOCl}$ treatment and export simulation. $\mathrm{NaOCl}$ which is considered as a biocide and mild vinegar solution which is acidic inhibited the bacterial growth in vase solutions increasing the vase life of cut foliage. A Bacillus sp. and a Staphylococcus sp. were associated with vase solutions of D. maculata and D. amoena cut foliage. Treatment with $\mathrm{NaOCl}$ and $\mathrm{Vim}^{\mathrm{TM}}$ satisfactorily extended the vase life of cut foliage of $D$. amoena and $D$. maculata respectively and could be recommended as preservatives for use during export.
\end{abstract}

Key words: cut foliage, export, sodium hypochlorite, vinegar, bacteria

\section{INTRODUCTION}

Species of Dieffenbachia Schott (Family Araceae) are house plants that tolerate a wide range of indoor conditions and low levels of sun light and humidity. They are popular in homes and indoor environments due to their colourful, large leaves with shades of green alternating with white or shades of yellow, in a wide variety of patterns. The commonest tropical species is Dieffenbachia maculata which has white or cream leaves with a very narrow green margin (Holttum and Enoch, 1997). Dieffenbachia can be easily grown in tropical countries as the plants enjoy a wide range of climatic conditions and grow without fertilization and care. Some varieties are common along roadsides, back yards and in uncultivated lands and especially favour and grow luxuriously under shade conditions. Cut foliage of Dieffenbachia has decorative value in floral arrangements and is currently exported to Middle Eastern countries in small quantities by Sri Lankan exporters. However, keeping cut foliage for a considerable time without much deterioration in quality and

*Corresponding author's email: kris@ kln.ac.lk freshness is a problem (Personal communication, Anuradha Foliage Nursery, Owitigala).

Various preservatives or biocides are currently used in Asia and the rest of the world to extend the vase life of floral and foliage products and these are relatively expensive. In addition, most effective preservatives such as silver nitrate $\left(\mathrm{AgNO}_{3}\right)$ and silver thiosulphate $\left[\mathrm{Ag}_{2}\left(\mathrm{~S}_{2} \mathrm{O}_{3}\right)\right]$ are undesirable for humans as silver is a heavy metal and disposal of residues have created environment problems globally (Philosoph-Hadas, 2002). The action of various preservatives in plant metabolism is to keep the tissue cells active and alive for a longer time to sustain the postharvest life of cut foliage and cut flowers (Butt, 2005). Relatively mild biocides such as sodium hypochlorite $(\mathrm{NaOCl})$ and aluminium sulphate $\left[\left(\mathrm{Al}_{2}\left(\mathrm{SO}_{4}\right)_{3}\right]\right.$ prevent the growth of bacteria in vase solutions even though, vase solution is alkaline. Acidic $\mathrm{pH}$ when maintained in vase solutions reduces bacterial growth and multiplication. Manipulating $\mathrm{pH}$ in vase solutions between 3.5 and 4.0 may help to overcome the bacterial problem and reduce vascular occlusion which could assist in 
lengthening the vase life of cut flower and foliage (Nell and Reid, 2000; Bhaskar et al., 2005). According to Singh et al.( 2002), the $\mathrm{pH}$ of the vase solution should be around 6.5-7.5 for most flowers. For better appearance of cut flowers or foliage, large amounts of soluble carbohydrates are required as osmolytes and substrates for respiration as well as for biosynthetic activities. Treatment with sucrose solution alone or in combination with a biocide has shown to improve the vase life of cut flowers and foliage (Reid and Dodge 1997; Kumar and Bhattacharjee, 2004; Hongyi and Jinzhi 2005; Ichimura et al., 2005). Pretreatment in combination with short term cold storage, further maintain the freshness and quality of cut foliage and flowers meant for export (Hongbo et al., 2003). The objectives of the study therefore, were to determine the effect of selected foliage preservatives, identified as eco friendly, in maintaining freshness and lengthening of vase life of cut foliage of two Dieffenbachia species under simulated export conditions.

\section{MATERIALS AND METHODS}

\section{Plant Material}

All experiments were conducted using leaves of Dieffenbachia maculata, 'Spotted dumbcane' and Dieffenbachia amoena, 'Tropic Snow' ('Tropic Topaz'). Dieffenbachia leaves were freshly harvested during the morning hours (between 8.30-10.00 am) from the botanical garden of the Department of Botany, University of Kelaniya. Third, fourth and fifth leaves from the tip of the plant were cut using a sharp cutter (Karunaratne, Green Farms Pvt. Ltd., personal communication), cut ends of leaves immersed in tap water and brought to the laboratory (Waithaka et al., 2001; Hettiarachchi and Balas, 2004). Cut foliage was cleaned to remove dust or any dirt using wet cotton wool (Butt, 2005).

\section{Preservatives used}

$1.75 \%$ of sodium hypochlorite (Clorox $^{\mathrm{TM}}$ Sdn. Bhd., Malaysia), 5\% vinegar (Reckitt Benckiser (Lanka) Ltd., Sri Lanka) and dish washing detergent (Vim ${ }^{\mathrm{TM}}$, Unilever, Sri Lanka Ltd.) were used in the study.

\section{Effect of continuous treatment with preservative solutions on vase life}

Initially, a preliminary experiment was conducted by placing cut foliage in different concentrations of selected preservative solutions; $0.016 \% \mathrm{v} / \mathrm{v} \mathrm{NaOCl}\left(160 \mu 11^{-1}\right.$ of $\left.1.75 \% \mathrm{NaOCl}\right)$, $0.16 \% \mathrm{v} / \mathrm{v}$ vinegar $\left(160 \mu \mathrm{l} \mathrm{l}^{-1}\right.$ of $5 \%$ vinegar $)$ and $0.16 \% \mathrm{v} / \mathrm{v} \operatorname{vim}^{\mathrm{TM}}\left(160 \mu \mathrm{l}^{-1}\right.$ of vim liquid detergent). All the solutions were prepared in tap water. $\mathrm{pH}$ of all treatment solutions were measured using a portable digital $\mathrm{pH}$ meter (model HI98107, Hanna instruments, Portugal) and conductivity using a digital conductivity meter (EC/TDS, HI98312, Hanna instruments, Portugal). Tap water without any added chemicals was used as the control. Length and width of leaves of cut foliage of D. maculata were measured using a ruler to evaluate any significant growth in leaves when foliage was kept in preservative solutions (Waithaka et al., 2001).

Eight Dieffenbachia cut leaves were placed in four replicate conical flasks (2 per flask) containing $250 \mathrm{ml}$ of each treatment solution. All flasks were kept in a cold room at $12-14^{0} \mathrm{C}$ and $85-90 \%$ RH for two days. After two days, samples were transferred to room temperature (28-30 ${ }^{0} \mathrm{C}$ ) and arranged on a laboratory bench according to completely randomized design (Pompodakis et al., 2004; Delaporte et al., 2005).

Once a week, leaf stalks were re-cut (a $2 \mathrm{~cm}$ piece was removed from the cut end) and all treatment solutions were replaced after recording the $\mathrm{pH}$ and conductivity. Solution uptake by leaves was also recorded by measuring the remaining volume in flasks and the mean values were calculated. When both leaves in each treatment flask started to senesce (based on an index used for yellowing of leaves -No yellowing $=0$, slight yellowing in tip or margin $=10 \%$, large patches of yellowing $=30 \%$, half of the leaf turned yellow $=50 \%, 2 / 3$ of the leaf turned yellow $=75 \%$ and leaf completely yellow $=100 \%)$, (Premawardane et al., 2000), the vase solution was subjected to dilution plate count and the number of colony forming units (CFU) of bacteria was recorded. Different bacterial isolates were sub cultured on nutrient agar (NA) and were identified to generic level by Gram's staining and biochemical tests (Benson, 2002). Vase life of Dieffenbachia cut foliage in each treatment was recorded and the mean vase life of the eight replicate leaves was calculated (Waithaka et al., 2001; Singh et al., 2004b). Vase life was expressed as the number of days taken from the beginning of each experiment until even one leaf started slight senescence according to the index of Premawardane et al. (2000) 
Effect of preservative solutions on vase life under simulated export conditions

Solutions of vinegar $(0.016 \%(\mathrm{v} / \mathrm{v})), \mathrm{NaOCl}$ $(0.016 \%(\mathrm{v} / \mathrm{v}))$ and dish washing detergent $(0.016 \%(\mathrm{v} / \mathrm{v}))$ were prepared and the $\mathrm{pH}$ and conductivity of the solutions were recorded. Cut leaves were randomly divided into four groups and the cut ends of the two replicate cut leaves were wrapped together with cotton wool using a rubber band and dipped in vinegar, $\mathrm{NaOCl}$, Vim $^{\mathrm{TM}}$ solution or tap water (control). Each treatment had eight replicate leaves (four bundles) (Waithaka et al., 2001). Four bundles of treated foliage were packed into three ply cardboard boxes $\left(18 \times 35 \times 40 \mathrm{~cm}^{3}\right)$ lined with Manila paper. All boxes ( 3 treatments + control) were kept in a cold room at $12-14^{0} \mathrm{C}$ and 85 90\% RH for two days. Subsequently, cut leaves were taken out and placed in relevant treatment solutions of vinegar, $\mathrm{NaOCl}, \mathrm{Vim}^{\mathrm{TM}}$ or tap water. Replacement of treatment solutions, recutting of leaf stalks, recording of $\mathrm{pH}$ and conductivity and isolation of bacteria were performed as for the continuous treatment. Vase life, solution uptake, leaf length and width of $D$. maculata and D. amoena cut foliage were recorded (Waithaka et al., 2001).

\section{Isolation and identification of bacteria}

Isolation of bacteria from vase solutions of D. maculata and D. amoena cut foliage was carried out using nutrient agar medium. Culture plates were incubated at room temperature $(28 \pm 2$ $\mathrm{C}^{0}$ ) on a laboratory bench for 2 days. Colony Forming Units of bacteria in selected dilutions were recorded. Several physiological and biochemical characters were noted through Gram's staining, endospore staining, motility determination, catalase activity, acid and gas production from glucose, citrate utilization, starch hydrolysis, indole production and oxidation or fermentation of glucose (Benson, 2002). Based on the results of biochemical tests, bacteria were identified with the aid of Bergey's Manual (Holt et al., 2000).

\section{Statistical analysis}

One-way ANOVA was performed using Minitab (version 14). All experiments were repeated once.

\section{RESULTS}

\section{Vase life}

During continuous treatment, the longest vase life of 45.1 days for D. maculata cut foliage was obtained with the tap water treatment (control), followed by Vim ${ }^{\mathrm{TM}}$ and vinegar solutions with a vase life of 41.9 days and 41.1 days respectively. When subjected to export simulation, D. maculata had the longest vase life of 38.4 days when foliage were treated with $\mathrm{Vim}^{\mathrm{TM}}$ solution. Cut foliage treated with $\mathrm{NaOCl}$ treatment also showed a relatively longer vase life of 37 days. D. amoena cut foliage, subjected to export simulation, gave the highest vase life of 21 days in $\mathrm{NaOCl}$ solution (Table 1 ).

Table 1. Vase life of Dieffenbachia maculata and $D$. amoena cut foliage subjected to continuous treatment with preservative solutions and export simulation.

\begin{tabular}{cccc}
\hline Treatment & $\begin{array}{l}\text { D. maculata } \\
\text { Continuous Treatment }\end{array}$ & $\begin{array}{c}\text { D. maculate with } \\
\text { Export Simulation }\end{array}$ & $\begin{array}{c}\text { D. amoena with } \\
\text { Export Simulation }\end{array}$ \\
\hline $\mathrm{NaOCl}$ & $33.2^{\mathrm{b}}$ & $37^{\mathrm{c}}$ & $21^{\mathrm{d}}$ \\
$\mathrm{Vim}$ & $41.9^{\mathrm{a}}$ & $38.4^{\mathrm{c}}$ & $18.9^{\mathrm{d}}$ \\
Vinegar & $41.1^{\mathrm{a}}$ & $33.1^{\mathrm{c}}$ & $19.2^{\mathrm{d}}$ \\
Tap water & $45.1^{\mathrm{a}}$ & & $18.2^{\mathrm{d}}$
\end{tabular}

Each data point represents the mean of 8 replicates

Means in each column followed by the same letter are not significantly different $(\mathrm{P}>0.05)$

by Tukey's multiple comparison test. 


\section{Changes in leaf length and width}

During continuous treatment, $3 \%$ and $4 \%$ difference in leaf length and width respectively were observed in cut foliage of $D$. maculata treated with vinegar solution and subjected to export simulation trials, compared to D. amoena cut foliage, where a significant difference in percent leaf length or width could not be observed. The leaves treated with tap water showed the lowest difference in leaf length and width. In D. amoena cut foliage subjected to export simulation trials, the percentage difference in leaf length and width was similar and relatively low in all four treatments (Tables 2 and 3 ).

Uptake of solutions by cut foliage

Uptake of solutions by $D$. maculata under continuous treatment was significantly higher in the tap water control (1.5 ml per leaf per day) than in the other three preservative solutions. In the export simulation trial, solution uptake by cut foliage of $D$. maculata and $D$. amoena was similar and low in all treatments and ranged from $0.15-0.42 \mathrm{ml}$ per leaf per day (Table 4).

Table 2. Percentage difference in leaf length in Dieffenbachia maculata and $D$. amoena cut foliage subjected to continuous treatment with preservative solutions and export simulation.

\begin{tabular}{lllc}
\hline Treatment & $\begin{array}{l}\text { D. maculata } \\
\text { Continuous Treatment }\end{array}$ & $\begin{array}{l}\text { D. maculata } \\
\text { Export Simulation }\end{array}$ & $\begin{array}{l}\text { D. amoena } \\
\text { Export Simulation }\end{array}$ \\
\hline $\mathrm{NaOCl}$ & $0.56^{\mathrm{a}}$ & $1.81^{\mathrm{c}}$ & $0.48^{\mathrm{d}}$ \\
$\mathrm{Vim}$ & $1.45^{\mathrm{a}}$ & $2.08^{\mathrm{c}}$ & $0.28^{\mathrm{d}}$ \\
Vinegar & $2.76^{\mathrm{b}}$ & $1.43^{\mathrm{c}}$ & $0.27^{\mathrm{d}}$ \\
Tap water & $1.67^{\mathrm{a}}$ & & $0.51^{\mathrm{e}}$ \\
\end{tabular}

Each data point represents the mean of 8 replicates.

Means in each column followed by the same letter are not significantly different $(\mathrm{P}>0.05)$ by Tukey's multiple comparison test.

Table 3. Percentage difference in leaf width of Dieffenbachia maculata and $D$. amoena cut foliage subjected to continuous treatment with preservative solutions and export simulation.

\begin{tabular}{lccc}
\hline Treatment & $\begin{array}{l}\text { D. maculata } \\
\text { Continuous Treatment }\end{array}$ & $\begin{array}{l}\text { D. maculata } \\
\text { Export Simulation }\end{array}$ & $\begin{array}{l}\text { D. amoena } \\
\text { Export Simulation }\end{array}$ \\
\hline $\mathrm{NaOCl}$ & $2.16^{\mathrm{a}}$ & $0.33^{\mathrm{c}}$ & $0.2^{\mathrm{d}}$ \\
$\mathrm{Vim}$ & $0.19^{\mathrm{a}}$ & $0.5^{\mathrm{c}}$ & $0.2^{\mathrm{d}}$ \\
Vinegar & $4.45^{\mathrm{b}}$ & $0.31^{\mathrm{c}}$ & $0.3^{\mathrm{d}}$ \\
Tap water & $0.37^{\mathrm{a}}$ & $0.25^{\mathrm{c}}$ & $0.7^{\mathrm{d}}$ \\
& & & \\
\hline
\end{tabular}

Each data point represents the mean of 8 replicates.

Means in each column followed by the same letter are not significantly different $(\mathrm{P}>0.05)$ by Tukey's multiple comparison test. 


\section{pH of vase solutions}

In $D$. maculata foliage subjected to continuous treatment with $\mathrm{NaOCl}$ (1.2) and vinegar (1.2) solutions, there was significant difference in $\mathrm{pH}$ after one week period. In the export simulation experiment with $D$. amoena, $\mathrm{pH}$ difference within a week was significantly high in $\mathrm{NaOCl}$ treated foliage. $\mathrm{pH}$ difference was lowest in $\mathrm{Vim}^{\mathrm{TM}}$ solution (Table 5).

\section{Conductivity of vase solutions}

The initial conductivity of $\mathrm{NaOCl}$ solution and tap water was slightly higher (0.04 and 0.06 $\mathrm{ms}$, respectively) than that of $\mathrm{Vim}^{\mathrm{TM}}$ and vinegar solutions $(0.02$ and $0.03 \mathrm{~ms}$ respectively). A slight change (0.001- $0.007 \mathrm{~ms}$ ) in conductivity was observed after one week in all three treatments in all the experiments except in the $\mathrm{NaOCl}$ treatment $(0.01-0.02 \mathrm{~ms})$.

\section{Growth of bacteria in vase solution}

Vase solutions in each replicate leaves were subjected to dilution plate count at the end of the vase life. Isolation of bacteria was conducted using NA plates. The CFU counts of bacteria under selected dilutions associated with $D$. maculate foliage treated with $\mathrm{NaOCl}$ solution was less (1.3) compared to other treatments where CFU ranged from 13-14. Vinegar solution was effective in reducing $\mathrm{CFU}$ in $D$. amoena to 5.3 compared to relatively higher numbers in other treatments that ranged from 23-98. Vim ${ }^{\mathrm{TM}}$ solution showed the highest CFU of 98.3 (Table 6)

Table 4. Uptake of solution by cut foliage of Dieffenbachia maculata and $D$. amoena subjected to continuous treatment with preservative solutions and export simulation.

\begin{tabular}{lccc}
\hline Treatment & $\begin{array}{l}\text { D. maculata } \\
\text { Continuous Treatment }\end{array}$ & $\begin{array}{l}\text { D. maculata } \\
\text { Export Simulation }\end{array}$ & $\begin{array}{l}\text { D. amoena } \\
\text { Export Simulation }\end{array}$ \\
\hline $\mathrm{NaOCl}$ & $0.42^{\mathrm{a}}$ & $0.17^{\mathrm{c}}$ & $0.32^{\mathrm{d}}$ \\
$\mathrm{Vim}$ & $0.31^{\mathrm{a}}$ & $0.17^{\mathrm{c}}$ & $0.24^{\mathrm{d}}$ \\
Vinegar & $0.31^{\mathrm{a}}$ & $0.19^{\mathrm{c}}$ & $0.24^{\mathrm{d}}$ \\
& $1.50^{\mathrm{b}}$ & & $0.39^{\mathrm{d}}$
\end{tabular}

Each data point represents the mean of 8 replicates

Means in each column followed by the same letters are not significantly different $(\mathrm{P}>0.05)$ by

Tukey's multiple comparison test.

Table 5. Differences in $\mathrm{pH}$ of vase solutions after one week period.

\begin{tabular}{lcccccc}
\hline Treatment & \multicolumn{2}{c}{$\begin{array}{c}\text { D. maculata } \\
\text { Continuous Treatment } \\
\text { Initial pH }\end{array}$} & $\begin{array}{c}\text { DH diff } \\
\text { pHaculate }\end{array}$ & \multicolumn{2}{c}{$\begin{array}{c}\text { D. amoena } \\
\text { Export Simulation } \\
\text { Initial pH }\end{array}$} & \multicolumn{2}{c}{ pH diff } & $\begin{array}{c}\text { Export Simulation } \\
\text { Initial pH }\end{array}$ & pH diff \\
\hline $\mathrm{NaOCl}$ & 8.95 & $1.23^{\mathrm{a}}$ & 9.13 & $1.57^{\mathrm{b}}$ & 8.56 & $0.98^{\mathrm{c}}$ \\
$\mathrm{Vim}$ & 7.87 & $0.48^{\mathrm{a}}$ & 8.0 & $0.76^{\mathrm{b}}$ & 7.96 & $0.42^{\mathrm{c}}$ \\
Vinegar & 6.47 & $1.2^{\mathrm{a}}$ & 6.46 & $1.31^{\mathrm{b}}$ & 6.3 & $1.46^{\mathrm{c}}$ \\
Tap water & 7.92 & $0.01^{\mathrm{a}}$ & 8.1 & $0.33^{\mathrm{b}}$ & 8.13 & $0.62^{\mathrm{c}}$ \\
& & & & & & \\
\hline
\end{tabular}

pH Each data point represents the mean of 8 replicates.

Means in each column followed by the same letter are not significantly different $(\mathrm{P}>0.05)$ by Tukey's multiple comparison test. 
Table 6. Colony Forming Units of bacteria in vase solutions of $D$. maculata and $D$. amoena cut foliage

\begin{tabular}{lccc}
\hline Treatment & $\begin{array}{l}\text { D. maculata } \\
\text { Continuous Treatment }\end{array}$ & $\begin{array}{l}\text { D. maculata } \\
\text { Export Simulation }\end{array}$ & $\begin{array}{l}\text { D. amoena } \\
\text { Export Simulation }\end{array}$ \\
\hline $\mathrm{NaOCl}$ & $1.3^{\mathrm{b}}$ & $1.0^{\mathrm{c}}$ & $23^{\mathrm{d}}$ \\
$\mathrm{Vim}$ & $24.0^{\mathrm{a}}$ & $1.7^{\mathrm{c}}$ & $98.3^{\mathrm{e}}$ \\
Vinegar & $13.0^{\mathrm{a}}$ & $2.7^{\mathrm{c}}$ & $5.3^{\mathrm{d}}$ \\
& $14.3^{\mathrm{a}}$ & & $41.7^{\mathrm{d}}$
\end{tabular}

Each data point represents the mean of 3 replicates.

Means in each column followed by the same letter are not significantly different $(\mathrm{P}>0.05)$ by Tukey's test.

\section{Isolation and identification of bacteria}

Based on Gram's staining and biochemical tests, 3 strains of bacteria were recorded from vase solutions of $D$. maculate foliage. One strain was identified as a Bacillus sp. and the other two as Grams' negative and positive rods. From vase solutions of D. amoena foliage subjected to the same tests, two Bacillus strains and one Staphylococcus strain were identified.

\section{DISCUSSION}

Keeping cut foliage for a considerable time without quality deterioration is critical during decorations. Cut foliage is normally exported via air freight which takes 2-3 days to reach a particular destination (Personal communication Anuradha Foliage Nursery, Owitigala). During the preparation of foliage for export and for the local market, cut foliage is usually dipped in tap water (Personal communication Anuradha Foliage Nursery, Owitigala). It has been reported that re-cutting rose stems (removing about $5 \mathrm{~cm}$ ) under water with a pair of sharp scissors or shears increased the vase life (Reid, 1998). In this study, attempts were made to develop cheap foliage preservatives which could improve the keeping quality of Dieffenbachia cut foliage during export.

Several researchers have indicated the usefulness of vase solutions in extending vase life of cut flowers. Wetting agents or detergents may be added to reduce the surface tension of water thereby promoting water uptake in cut stems (Reid, 2000). Many flowers attain best quality when treated with a solution containing only a biocide (e.g. $\mathrm{NaOCl}$ ), or biocide and a wetting agent (Reid, 2000; Casey and Parrella,
1998). Reid (1998) reported that a vase solution with $1 / 4$ teaspoon household bleach (e.g. Clorox) extended the vase life of cut roses. A research trial indicated that $\mathrm{NaOCl}(50 \mathrm{ppm})$ when combined with $1.5 \%$ sucrose solution significantly improved the vase life of the ferns, Blechum gibbum (Bostoniensis) and Nephrolepis exaltata (Golden Boston) (Singh et al., 2004a).

Acidic $\mathrm{pH}$ in vase solutions is known to be important in preventing blocking of stems by bacteria (Nell and Reid, 2000). $\mathrm{NaOCl}$ is an alkaline biocide which controls bacteria in the medium. Vinegar is an acidic solution which also controls bacteria in the medium due to the acidic $\mathrm{pH}$. According to our findings, both treatments were satisfactory in controlling bacterial growth in vase solutions and cut ends of stems by facilitating the water flow in stems.

During the present study, increased solution uptake was associated with preservatives which had a slightly high pH (e.g NaOCl with pH 8-9). In contrast, it has been reported previously that low $\mathrm{pH}$ solutions enhance cut rose flower water relations and vase life (Pompodakis et al., 2004). According to previous reports, lowering the acidity of vase solutions to $\mathrm{pH} 3.5$ - 4.5 allowed maximum uptake of water by the cut stems (Reid, 2000). According to Premawardena et al. (2000), carbonated beverages such as 7- UP ${ }^{\mathrm{TM}}$ at a concentration of $25 \%$ is best in treating cut flower Gladiolus to lengthen vase life. Although the composition of this beverage is not known, 7- UP ${ }^{\mathrm{TM}}$ contains citric acid, sugars and carbon dioxide. Part of the gas is expected to go into solution forming carbonic acid. Citric acid and carbonic acid reduce microbial growth in the vase solution by lowering the $\mathrm{pH}$. Post harvest quality and vase life of cut anthurium flowers 
(Anthurium andraeanum) have been improved by subjecting to short term heat treatment $\left(60^{\circ} \mathrm{C}\right.$, $15 \mathrm{~s})$ and 'ultrasonic treatment' (1 $\mathrm{min})$ (Hettiarchchi and Balas, 2005)

The biocides in vase solutions kill bacteria in the medium and on cut ends of stems (Reid, 2000). When cut flower stems are placed in water, microorganisms that are present grow rapidly, feeding on the sap that bleeds from the cut stem. It has been shown that within a day of placing a freshly cut rose stem in a clean vase containing tap water, about 30 million bacteria may be present in $30 \mathrm{ml}$ of vase water. These bacteria quickly clog up the xylem tissue that conducts water in the flower stem and result in premature wilting of flowers and foliage (Reid, 2000).

$\mathrm{NaOCl}$ treatment and vinegar, controlled CFU of bacteria in vase solutions compared to tap water control in this study. Chlorine prepared from bleaching powder i.e. $\mathrm{CaOCl}_{2}$ at $50 \mathrm{ppm}$ in a vase solution, significantly decreased the bacterial count in vase water and improved the keeping quality in seven commercial cultivars of roses (Grand Gala, Sangria, First Red, Kiss, Confidence, Starlite and Pareo) (Singh et al., 2004b). It has been shown that vascular occlusion caused by bacteria shortened the vase life of cut roses (Ichimura et al., 2005). Therefore, reduced number of $\mathrm{CFU}$ in $\mathrm{NaOCl}$ and vinegar treatments may have resulted in less vascular clogging and hence continuous uptake of solution.

A study on bacterial and fungal plugging of rose stems resulting in reduction of water uptake showed that bacteria like Pseudomonas, Enterobacter, Aeromonas, Erwinia and Corynebacteria are predominant in vase water (Ghosh, 1998). During the present study, three different Bacillus strains and one Staphylococcus strain associated with vase solutions were identified. It is important to highlight that Xanthomonas campestris which has been reported as a serious bacterial pathogen and a causative agent of leaf spot, tipburn and bacterial leaf blight diseases of Dieffenbachia leaves ((http://www.extension.umn.edu/distribution/hor ticulture/DG1170.html, 09.06.2006) was not present in any of the vase solutions. Xanthomonas campestris infected foliage pose a great threat to the ornamental plant export industry.

According to the findings of this study, all three treatments tested gave satisfactory results in extending vase life of cut foliage of $D$. maculata subjected to export simulation. Further research is necessary to identify the cost effective concentrations of the above treatments before they could be recommended as preservatives for vase life extension.

\section{ACKNOWLEDGEMENTS}

We gratefully acknowledge the assistance provided by the technical staff of the Department of Botany, and the trained gardener, $\mathrm{Mr}$. Padmasiri Perera, University of Kelaniya.

\section{REFERENCES}

Benson, H. J. (2002). Microbiological Applications, Laboratory Manual in General Microbiology. 8th Edition. McGraw Hill, Boston. Pp. 181.

Bhaskar, V. V., Rao, P. V. and Reddy, R. S. (2005). Influence of germicides on the physiological and biochemical changes in the flower petals during vase life period of cut rose cv. first red. Indian Journal of Horticulture $\mathbf{6 2}$ (2): 171-174.

Butt, S. J. (2005). Extending the vase life of roses (Rosa hybrida) with different preservatives. International Journal of Agriculture and Biology 7 (1): 97-99.

Casey, C. and Parrella, M. (1998). California cut roses: Production and Preservation - Part II. Growing points, Department of Environmental Horticulture, University of California, Davis. 2 (4): 1-3.

Delaporte, K. L., Klieber, A. and Seddgley, M. (2005). Effect of sucrose at different concentrations and cold dry storage on vase-life of three ornamental Eucalyptus species. Journal of Horticultural Science and Biotechnology $\mathbf{8 0}$ (4): 471-475.

Ghosh, S. P. (1998). Research and development in horticulture and commercial floriculture. Indian Horticulture 43 (1): 7-11.

Hettiarachchi, M. P. and Balas, J. (2004). Effects of cold storage on post harvest keeping quality of Gloriosa (Gloriosa superba L.) flowering stems. Tropical Agricultural Research and Extension 7: 88-94. 
Holttum, R. E. and Enoch. (1997). Gardening in the tropics. (1st Edition) Singapore. Pp. 217.

Hongbo, Z., Guidi, S., Suzhen, H., Weiming, G. and Mingyun, X. (2003). The effect of the different precooling and vase solutions on preservation of Iris xiphium L. var. hybridum cv. Rosarlo after cutting. Journal of Plant Resources and Environment 12 (4): 31-34.

Holt, John G., Noel, R. Krieg, Peter, H.A. Sneath, James T. Staley and Stanley, T. Williams. (2000). Bergey's manual of determinative bacteriology. ( $9^{\text {th }}$ ed.) Lippincott Williams \& Wilkins, USA.

Hongyi L. and Jinzhi, L. (2005). Effects of pretreatment solution containing $\mathrm{B}_{9}$ on senescence of cut flower of lily. Plant Physiology Communications 41 (1): 34-36.

Ichimura K., Kishimoto, M., Norikoshi, R., Kawabata, Y. and Yamada, K. (2005). Soluble carbohydrates and variation in vase-life of cut rose cultivars 'Delilah' and 'Sonia'. Journal of Horticultural Science \& Biotechnology 80 (3): 280-286.

Kumar, V. and Bhattacharjee, S. K. (2004). Postharvest life and quality of "Mercedes" cut roses as influenced by pulsing with Dfructose+8-HQC, Alar and dry cool storage. Scientific Horticulture. 9: 171-179.

Nell, T. A. and Reid, M. S. (2000). Flower and plant care. Society of American Florists, USA.

Philosoph-Hadas, S. (2002). Postharvest handling of cut flowers. Course in postharvest biology, The volvanic center, Bet-Dagan 50250, Israel.

Pompodakis, N. E., Joyce, D. C., Terry, L. A. and Lydakis, D. E. (2004). Effects of vase solution $\mathrm{pH}$ and abscisic acid on the longevity of cut 'Baccara' roses. Journal of Horticultural Science \& Biotechnology 79 (5): 828-832.
Premawaedena, P. S., Peiris, B. C. N. and Peiris, S. E. (2000). Effects of selected post-harvest treatments on vase life of cut flower, Gladiolus (Gladiolus grandiflorus). Tropical Agricultural Research 12: 325-333.

Reid, M. S. (1998). Postharvest care of cut roses. Growing Points, Department of Environmental Horticulture, University of California, Davis 2 (4): 4-6.

Reid, M. S. (2000). Fresh flower foods. California Ornamental Research Federation News 4 (3): 1-4.

Reid, M. S. and Dodge, L. (1997). Produce facts - Carnations. Recommendations for Maintaining postharvest Quality. Postharvest Outreach Program. Department of Environmental Horticulture, University of California, Davis 19 -20 .

Singh, M. K., Voleti, S. R. and Sindhu, S. S. (2002). Postharvest handling and care of cut flowers. Postharvest Management, Indian Horticulture Pp. 45.

Singh, P., Singh, K., and Kumar, R. (2004a). Effect of chemical treatments on vase life of ferns. Advances in Horticultural Science 18 (2): 60-62.

Singh, K., Singh P. J. and Kumar, R. (2004b). Effect of some chemicals on keeping quality of cut roses. Advances in Horticultural Science 18 (4): 161-167.

Waithaka, K., Reid, M. S. and Dodge, L. L. (2001). Cold storage and flower keeping quality of cut tuberose (Polianthes tuberosa L.). Journal of Horticultural Science \& Biotechnology 76 (3): 271-275. 